\title{
MODEL REGRESI PENGARUH RASIO KEUANGAN TERHADAP KEUNTUNGAN BERSIH PERUSAHAAN ADHI KARYA (PERSERO) TBK.
}

\author{
Rukmono Budi Utomo \\ Program Studi Pendidikan Matematika FKIP UMT \\ J1. Perintis Kemerdekaan I No 33, Cikokol, Kota Tangerang, Banten, \\ rukmono.budi.u@mail.ugm.ac.id
}

\begin{abstract}
ABSTRAK
Penelitian ini dilakukan untuk medapatkan model regresi yang menjelaskan pengaruh rasio keuangan terhadap pendapatan bersih pada Perusahaan Adhi Karya (Persero) Tbk. Penelitian ini menggunakan data Indonesia Capital Market Directory (ICMD) yang disediakan oleh Institute for Economic and Financial Research (IEFR). Data diolah dengan menggunakan bantuan SPSS untuk memperoleh model regresi yang dimaksud. Hasil dari penelitian ini adalah model regresi linier dengan keakuratan $82.6 \%$ yakni keuntungan bersih perusahaan dipengaruhi oleh rasio keuangan NPM dan sisanya dipengaruhi oleh faktor lain. Model yang terbentuk sudah melalui berbagai uji antara lain uji F, uji-t, dan uji ekonomterik.
\end{abstract}

Kata Kunci : Model Regresi, Rasio Keuangan, Keuntungan Bersih, Adhi Karya

\section{Pendahuluan}

Perseroan Terbatas (PT) Adhi Karya

(Persero) Tbk atau lebih dikenal dengan PT.

Adhi (Persero) Tbk merupakan perusahaan publik yang bergerak di bidang konstruksi. Perusahaan ini didirikan pada Tanggal 11 Maret 1960 dan memiliki kantor pusat di Jakarta.

PT Adhi Karya (Persero) Tbk memiliki beberapa anak perusahaan, antara lain PT Adhi Persada Beton, PT Adhi Persada Gedung dan PT Adhi Persada Properti. Anak perusahaan PT Adhi Karya (Persero) Tbk tersebut secara garis besar bergerak di sektor yang sama dengan perusahaan induknya yakni pada setor konstruksi.
Berdasarkan data Indonesia Capital Market Directory (ICMD) yang disediakan oleh Insitute for Economic and Financial Research (IEFR), PT Adhi Karya (Persero) Tbk merupakan salah satu perusahaan yang memiliki rekam jejak kinerja baik. Hal ini dibuktikan dari pendapatan bersih perusahaan yang dari tahun ke tahun cenderung mengalami peningkatan.

Pada tahun 2008, PT Adhi Karya (Persero) Tbk membukukan pendapatan bersih sebesar Rp 81 milyar. Pada tahun 2009, perusahaan ini mampu meningkatkan pendapatan bersihnya menjadi Rp 166 milyar. 
Kinerja perusahaan ini mampu ditingkatkan sehingga pada tahun 2010 pendapatan bersih PT Adhi Karya (Persero) Tbk tercatat sebesar Rp 189 milyar atau mengalami peningkatan sebesar $\mathrm{Rp} 23$ milyar dengan persentase 12,16 \% Sayangnya prestasi ini tidak dapat dipertahankan pada tahun setelahnya.

Pada tahun 2011, pendapatan bersih PT Adhi Karya (Persero) Tbk menurun menjadi Rp 183 milyar dengan nilai penurunan sebesar Rp. 3 Miliar dari periode tahun sebelumnya. Pada tahun 2012, perusahaan ini kembali menunjukkan prestasi kinerjanya dengan membukukan pendapatan bersih sebesar Rp. 214 Miliar atau meningkat Rp 31 Milyar dari tahun sebelumnya.

Berdasarkan data itu semua, maka dapat disimpulkan bahwa perusahaan ini merupakan perusahaan dengan kinerja yang cukup baik. Hal ini dapat dilihat dari peningkatan pendapatan bersih perusahaan dari tahun ke tahun meski diwarnai dari penurunan pendapatan bersih pada periode tahun 2011.

Ada banyak faktor yang dapat mempengaruhi pendapatan bersih suatu perusahaan, misalnya banyaknya jumlah proyek yang ditangani atau diperoleh dan pengeluaran rutin dari perusahaan yang harus diminimalkan.
Terlepas dari pada itu semua, ternyata banyak penelitian yang mengatakan bahwa peningkatan pendapatan bersih suatu perusahaan banyak dipengaruhi oleh rasio keuangan, salah satunya penelitian yang dilakukan oleh Rukmono Budi Utomo.

Rukmono Budi Utomo dalam penelitiannya berhasil membuat model regresi yang menjelaskan keuntungan perusahaan manufaktur ditinjau dari rasio keuangan. Penelitian ini telah terbit pada jurnal silogisme Universitas Muhammadiyah Ponorogo Volume 2 No. 1 bulan Juni tahun 2017. Hasil dari penelitian Rukmono Budi Utomo menyimpulkan bahwa rasio keuangan memiliki sumbangsih pengaruh terhadap pendapatan bersih perusahaan sebesar 60,8 persen.

Penelitian yang lain dan juga dilakukan oleh Rukmono Budi Utomo dengan topik yang sama yakni seputar pengaruh rasio keuangan terhadap pendapatan bersih perusahaan juga telah dipublikasikan pada jurnal Gammath Volume 2 Nomer 1 bulan Maret tahun 2017 dan jurnal silogisme volume 3 nomer 2 bulan desember tahun 2018.

Pada penelitian yang dipublikasikan pada jurnal Gammath, Rukmono Budi Utomo menggunakan metode Lower-Upper Gauss untuk membuat model matematika 
yang menjelaskan pengaruh rasio keuangan terhadap persentase laba perusahaan manufaktur, sedangkan penelitian yang dipublikasikan pada jurnal silogisme, peneliti tersebut mengambil judul penelitian seputar perbandingan keakuatan model regresi dengan menggunakan metode Dekomposisi Lower-Upper (LU) Gauss dan Backward.

Berdasarkan hasil penelitian yang telah ada dan diuraikan di atas, maka rasio keuangan memiliki pengaruh yang cukup besar terhadap peningkatan pendapatan bersih suatu perusahaan. Oleh karena itu, dalam penelitian ini akan coba dikaji pula pengaruh rasio keuangan terhadap peningkatan bersih perusahaan PT Adhi Karya (Persero) Tbk. Penelitian ini akan menghasilkan suatu model matematis regresi linier yang menjelaskan pengaruh rasio keuangan terhadap peningkatan pendapatan bersih di perusahaan ini.

Rasio keuangan yang digunakan dalam penelitian ini antara lain ROA, ROE, GPM, OPM, NPM, Payout Ratio (PR), dan Yield. Rasio keuangan tersebut digunakan untuk melihat pengaruhnya terhadap peningkatan pendapatan bersih perusahaan PT Adhi Karya (Persero) Tbk. Dengan demikian dapat diprediksi pendapatan perusahaan tersebut di tahun mendatang.
Dalam penelitian ini, disamping menghasilkan model regresi linier yang menjelaskan pengaruh rasio keuangan terhadap peningkatan pendapatan bersih perusahaan PT Adhi Karya (Persero) Tbk lebih lanjut akan dilakukan berbagai macam uji statistik yang meliputi uji-F, uji-t dan uji ekonometrik yang meliputi uji normalitas, uji homogenitas, uji linearitas, uji non multkolinearitas, uji non autokorelasi dan uji. Uji-uji ini penting dilakukan sebagai suatu syarat dalam analisis regresi.

\section{Metode Penelitian}

Metode penelitian yang dilakukan dalam penelitian ini menggunakan data rasio keuangan pada ICMD yang disediakan oleh IEFR. Data yang diperoleh kemudian dirapihkan dan selanjutnya diolah dengan menggunakan metode Stepwise menggunakan perangkat lunak SPSS. Hasil dari pengolahan data tersebut mengasilkan model regresi linier. Setelah model regresi diperoleh, kemudian dianalisa dan dilakukan uji analisis regresi meliputi uji-F, uji-t dan uji ekonometrik. Model yang memenuhi semua asumsi dan uji dalam analisis regresi digunakan sebagai model yang menjelaskan pengaruh rasio keuangan terhadap persentase pendapatan bersih perusahaan PT Adhi Karya (Persero) Tbk. 


\section{Hasil dan Pembahasan}

Berdasarkan data ICMD yang disediakan oleh IEFR diperoleh data rasio keuangan dan pendapatan bersih PT Adhi Karya (Persero) Tbk. dari tahun 2008 sampai dengan 2012 yang dijelaskan dalam tabel 1 dibawah ini.

Tabel 1. Rasio Keuangan dan pendapatan bersih PT Adhi Karya (Persero) Tbk.

\begin{tabular}{lccccc}
$\quad$ Rasio & $\begin{array}{c}\text { Desem } \\
\text { Ker }\end{array}$ & $\begin{array}{c}\text { Desem } \\
\text { ber }\end{array}$ & $\begin{array}{c}\text { Desem } \\
\text { ber }\end{array}$ & $\begin{array}{c}\text { Desem } \\
\text { ber }\end{array}$ & $\begin{array}{c}\text { Desem } \\
\text { ber }\end{array}$ \\
& 2008 & 2009 & 2010 & 2011 & 2012 \\
ROA (\%) & 2.39 & 5.89 & 6.51 & 5.34 & 5.38 \\
ROE (\%) & 20.97 & 45.37 & 37.26 & 32.96 & 35.85 \\
GPM (\%) & 8.62 & 9.75 & 13.55 & 11.93 & 13.68 \\
OPM (\%) & 5.54 & 6.96 & 9.71 & 6.18 & 7.09 \\
NPM (\%) & 1.23 & 2.15 & 3.34 & 2.73 & 2.8 \\
Payout Ratio & 25.44 & 30.75 & 30.75 & 29.92 & 29.21 \\
$\begin{array}{l}\text { (\%) } \\
\text { Yield (\%) }\end{array}$ & 4.26 & 6.89 & 3.55 & 5.23 & 4.98 \\
$\begin{array}{l}\text { Net Income } \\
\text { (Miliyar Rp) }\end{array}$ & 81 & 166 & 189 & 183 & 214 \\
\hline
\end{tabular}

Setelah diberikan data pada tabel 1 di atas, langkah selanjutnya dilakukan input data pada perangkat lunak SPSS. Setelah itu dilakukan analisis regresi linier berganda dengan menggunakan metode Stepwise untuk memperoleh model regresi yang menjelaskan pengaruh rasio keuangan pendapatan bersih perusahaan PT Adhi Karya (Persero) Tbk. Hasil pengolahan data dengan SPSS tersebut adalah model regresi dengan koefisien model yang dijelaskan pada tabel 2 koefisien sebagai berikut.

Tabel 2. Koefisien Model Regresi.

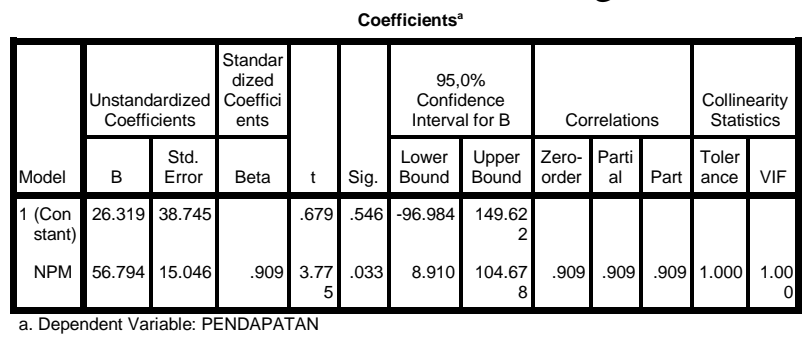

Pada tabel 2 di atas, terlihat bahwa hanya rasio keuangan NPM saja yang berpengaruh terhadap pendapatan bersih PT Adhi Karya (Persero) Tbk dengan nilai koefisien NPM sebesar 56,794 sehingga model regresi yang menjelaskan pengaruh rasio keuangan terhadap pendapatan bersih perusahaan PT Adhi Karya (Persero) Tbk adalah $Y=26,31956+794 N P M$, dengan $Y$ adalah pendapatan bersih perusahaan.

Setelah diperoleh model regresi, selanjutnya akan dilakukan uji $\mathrm{F}$ atau uji kecocokan model dan uji-t atau uji parsial model. Uji F dilakukan dengan melihat nilai signifikansi. Jika nilai signifikansi model < $\alpha=0,05$,maka uji $\mathrm{F}$ terpenuhi atau dengan kata lain model cocok. Pada tabel 3 Anova di bawah ini, terlihat bahwa nilai signifikansi model adalah $0,033<\alpha=0,05$. Hal ini memberi arti bahwa model regresi yang terbentuk sudah sesuai.

Tabel 3 Anova

ANOVA $^{\mathrm{b}}$

\begin{tabular}{|c|c|c|c|c|c|c|}
\hline \multicolumn{2}{|c|}{ Model } & $\begin{array}{l}\text { Sum of } \\
\text { Squares }\end{array}$ & df & $\begin{array}{c}\text { Mean } \\
\text { Square }\end{array}$ & $F$ & Sig. \\
\hline \multirow[t]{3}{*}{1} & $\begin{array}{l}\text { Regress } \\
\text { ion }\end{array}$ & 8545.792 & 1 & $\begin{array}{r}8545.79 \\
2\end{array}$ & $\begin{array}{r}14.24 \\
8\end{array}$ & $.033^{a}$ \\
\hline & Residua & 1799.408 & 3 & 599.803 & & \\
\hline & Total & $\begin{array}{r}10345.20 \\
0\end{array}$ & 4 & & & \\
\hline
\end{tabular}

a. Predictors: (Constant), NPM

b. Dependent Variable: PENDAPATAN 
Setelah dilakukan uji F, selanjutnya dilakukan uji-t atau uji parsial model. Karena model regresi yang terbentuk hanya tersusun dari rasio keuangan NPM, maka uji-t yang dilakukan hanya diperuntukkan bagi NPM. Uji-t dilakukan dengan melihat nilai signifikansi. Jika nilai signifikansi NPM $<\alpha$ $=0,05$, maka uji-t terpenuhi atau dengan kata lain rasio keuangan NPM berpengaruh terhadap model regresi yang terbentuk. Pada tabel 2 di atas, terlihat pula bahwa nilai signifikansi sebesar $0,033<\alpha=0,05$, yang artinya rasio keuangan NPM memiliki pengaruh terhadap model regresi yang terbentuk.

Setelah dilakukan uji $F$ dan uji-t maka selanjutnya dilakukan uji ekonometrik yakni melihat kenormalan, kelinieritasan, dan kehomogenitasan data. Pada gambar 1,2, dan 3 di bawah ini secara berturut-turut terlihat bahwa data yang digunakan dalam penelitian bersifat normal. Dengan demikian uji normalitas terpenuhi. Selanjutnya pada gambar 2, terlihat bahwa data yang digunakan terletak di sekitar garis linier, dengan kata lain hal ini menjelaskan uji linieritas terpenuhi. Selanjutnya pada gambar 3 terlihat bahwa data yang digunakan tersebar secar acak dan tidak membentuk pola. Hal ini memberi arti bahwa uji homogenitas terpenuhi.

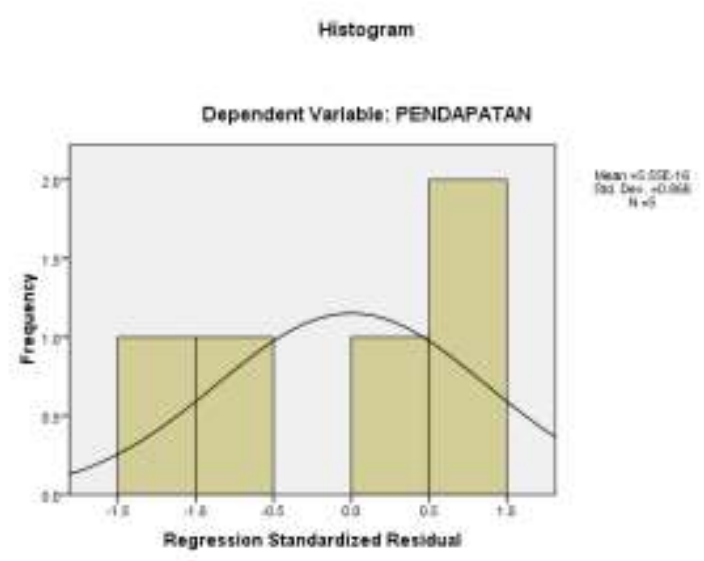

Gambar 1. Kenormalan Data

Normal P.P Plot of Regression Standardized Residual

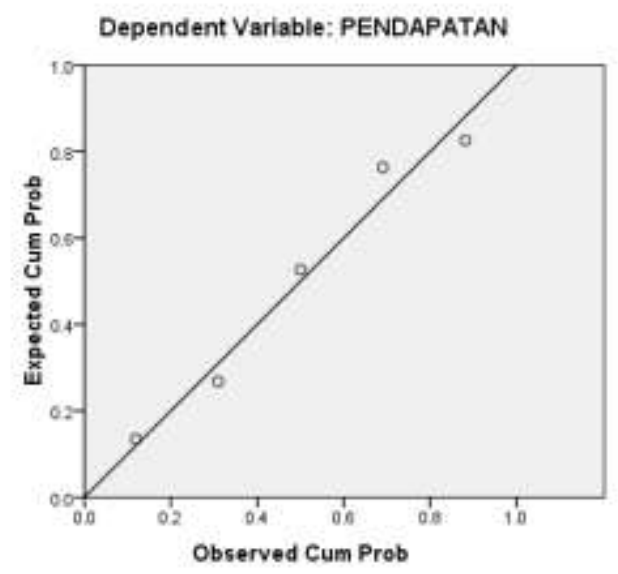

Gambar 2. Kelinieran Data

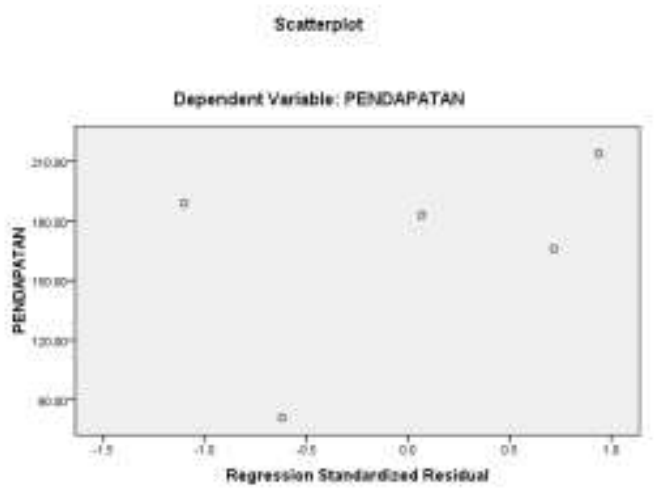

Gambar 3. Kehomogenan Data 
Setelah dilakukan uji normalitas, uji linieritas, dan uji homogenitas, selanjutnya dilakukan uji non multikolinieritas, uji non autokorelasi, dan uji asumsi heterokedastisitas. Uji non multikolinieritas dilakukan dengan melihat nilai VIF. Jika nilai VIF pada NPM < 5 maka model regresi yang terbentuk terbebas dari multikolinieritas. Pada tabel 2 di atas terlihat bahwa nilai VIF NPM = 1 dan $<5$. Dengan demikian uji non multikolinieritas terpenuhi. Selanjutnya uji non autokorelasi dilihat dari kriteria Durbin-Watson (DW). Pada tabel 4 di bawah ini terlihat bahwa nilai DW $=2.410$ dan berada di antara 2 dan 3. Berdasarkan hal tersebut, uji non autokorelasi terpenuhi.

Tabel 4. Nilai Durbin-Watson

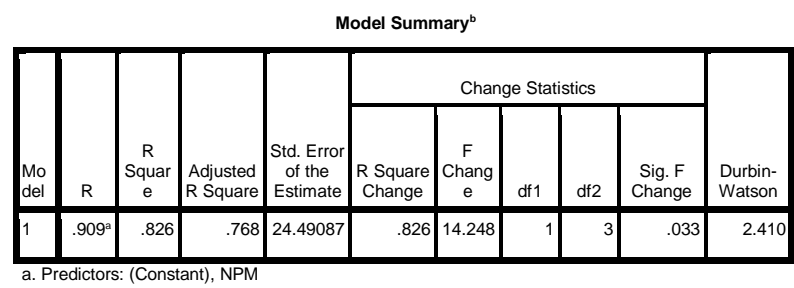

b. Dependent Variable: PENDAPATAN

keuangan yang digunakan hanya NPM, maka secara otomatis uji asumsi heterokedastisitas terpenuhi. Hal ini juga dapat dilihat dari nilai koefisien model sebesar 0,679 yang lebih besar dari $\alpha=0,05$.

Dengan dilakukannya uji F, uji-t dan uji ekonometrik yang meliputi uji normalitas, linearitas, homogentas, non multkolinearitas, non autokorelasi dan uji heteokedastisitas, maka hasil dari penelitian telah lengkap.

\section{Simpulan}

Kesimpulan yang dapat diambil dari penelitian ini diuraikan pada point sebagai berikut:

1. Model regresi yang terbentuk untuk menjelaskan pengaruh rasio keuangan terhadap pendapatan bersih PT Adhi Karya (Persero) Tbk adalah $Y=26,31956+794 N P M$

2. Model di atas memiliki keakuratan sebesar $82.6 \%$ selebihnya model dipengaruhi oleh faktor lain yang tidak dikaji pada penelitian ini. Keakuratan model dapat dilihat pada tabel 4 di atas.

3. Model yang terbentuk telah melalui berbagai uji antara lain uji F, uji-t dan uji ekonometrik yang meliputi uji normalitas, linearitas, homogentas, non multkolinearitas, non autokorelasi dan uji heteokedastisitas.

4. Untuk penelitian lebih lanjut ( Saran ) sebaiknya dapat menggunakan faktor-faktor lain yang diperkirakan dapat mempengaruhi pendapatan bersih PT Adhi Karya (Persero) Tbk, disamping rasio keuangan yang digunakan dalam penelitian ini. 


\section{Pustaka}

anonim. 2019. PT Adhi Karya (Persero) Tbk. https://id.m.wikipedia.org/wiki/Adhi_

Karya. Diakses Sabtu, tanggal 30 Maret tahun 2019 jam 22.53 WIB.

Utomo,Rukmono Budi. 2017. Model Regresi Persentase Keuntungan Perusahaan Manufaktur Ditinjau Dari Faktor Rasio Keuangan Berdasarkan Data ICMD. Jurnal Silogisme Vol. 2 No. 1.

Utomo,Rukmono Budi. 2017. Model Matematika Pengaruh Rasio Keuangan Terhadap Persentase Laba Perusahaaan Manufaktur Dengan Menggunakan Metode Dekpomposisi Lower- Upper Gauss. Jurnal Gammath Vol. 2 No. 1.

Utomo, Rukmono Budi. 2018. PerbandinganKeakuratan Model Regresi Menggunakan Metode Dekomposisi LU Gauss dan Backward. Jurnal Silogisme Vol. 3 No. 2. 
